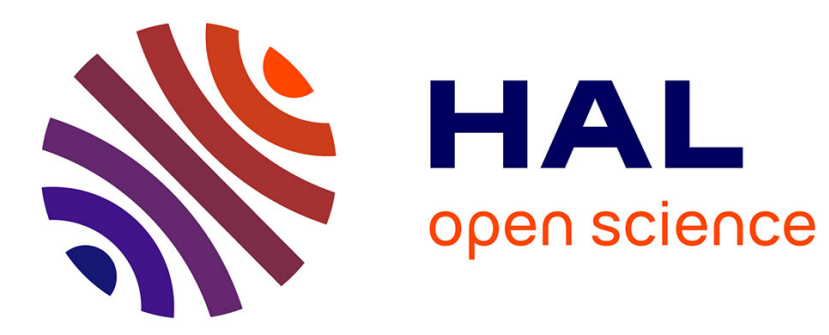

\title{
Alpine deep-seated gravitational slope deformation and the Messinian Salinity Crisis
}

Y. Drouillas, T. Lebourg, S. Zerathe, Jean-Claude Hippolyte, Raphaël

Chochon, M. Vidal, R. Besso

\section{- To cite this version:}

Y. Drouillas, T. Lebourg, S. Zerathe, Jean-Claude Hippolyte, Raphaël Chochon, et al.. Alpine deepseated gravitational slope deformation and the Messinian Salinity Crisis. Landslides, 2021, 18, pp.539549. 10.1007/s10346-020-01504-5 . hal-02995317

\section{HAL Id: hal-02995317 \\ https://hal.science/hal-02995317}

Submitted on 23 Nov 2020

HAL is a multi-disciplinary open access archive for the deposit and dissemination of scientific research documents, whether they are published or not. The documents may come from teaching and research institutions in France or abroad, or from public or private research centers.
L'archive ouverte pluridisciplinaire HAL, est destinée au dépôt et à la diffusion de documents scientifiques de niveau recherche, publiés ou non, émanant des établissements d'enseignement et de recherche français ou étrangers, des laboratoires publics ou privés. 


\title{
Alpine deep-seated gravitational slope deformation and the Messinian Salinity Crisis
}

\author{
Y. Drouillas, T. Lebourg, S. Zerathe, J. C. Hippolyte, R. Chochon, M. Vidal, and R. Besso
}

\author{
Submitted version. \\ The final publication is available at link.springer.com". \\ DOI 10.1007/s10346-020-01504-5 \\ Landslides \\ ISSN 1612-510X \\ https://www.springer.com/journal/10346/
}

\section{Y. Drouillas, T. Lebourg, R. Chochon, M. Vidal, R. Besso}

Université Côte d'Azur, CNRS, Observatoire de la Côte d'Azur, IRD, Géoazur, Valbonne Sophia Antipolis, France

\section{T. Lebourg}

ESPACE UMR 7300, UNS, UCA, Nice, France

\section{S. Zerathe}

ISTerre, CNRS, Q4 IRD, Université Grenoble Alpes, F-38041, Grenoble, France

\section{J. C. Hippolyte}

Aix Marseille Univ, CNRS, IRD, INRAE, Coll France, CEREGE, Aix-en-Provence, France, 13545, Aix-en-

Provence, France

\begin{abstract}
:
The southern part of the French Alps is studied for years in mapping and understanding of large-scale gravitational deformations. The identification and the knowledge of large-scale slope deformation (deep-seated gravitational slope deformation or DSGSD and deep-seated landslide or DSL) in the previous work of Jomard (2006) and Zerathe (2013) open a new vision of landslide processes with the reinterpretation of their dynamics and the characterization of the time scales involved. We identify DSGSD(10.109 m3) in the Var Valley associated with geological and geomorphological anomalies linked to the Messinian Salinity Crisis(MSC) and the alpine orogenesis. We use field observations, geological information (geological map, boreholes), and topographic analysis performed in a GIS environment in order to describe these anomalies. This old and partly eroded slide mass is associated with three typical DSGSD features: (1) a double-crested ridge, the Sinne Valley, (2) a large formation $(2.7 \times 108 \mathrm{~m} 3)$ of slope deposit dated from the Messinian (Carros breccia), and (3) the kilometric deviation (1 to $2 \mathrm{~km}$ ) of the Var River. We relate all these anomalies to the MSC (5.97 to $5.46 \mathrm{Ma}$ ) and the incision of deep canyons during this period related to this major eustatic variation $(\approx 1300 \mathrm{~m})$. The incision of the canyon triggered the collapse process of the DSGSD of the Sinne Valley and so destabilized the entire massif. At present, three DSLs resulting from the DSGSD deformation are still present in the area in a dormant state. Indeed, since the infilling of the Var Canyon during the Pliocene, the activity of the DSGSD has stopped.
\end{abstract}


Keywords: Deep-seated gravitational slope deformation. Subalpine chains. Messinian Salinity Crisis. Gravitational slope evolution. Eustatic variation.

\section{I- Introduction}

For several decades, studies on gravitational phenomena have focused on the geomorphological characteristics and dynamic processes of large landslides to better understand the phenomenon and especially their evolution and their impact on the landscapes. The role played by landslides in mountain ranges is varied, but they are above all a vector of erosion and mass displacement. Our studied gravitational movements are deep-seated gravitational slope deformations (DSGSDs) (greater than $109 \mathrm{m3}$ ) (defined by Malgot 1977), and they can involve an entire hill slope. They are complex and require precise three-dimensional or even fourdimensional investigations with time considered. Yet these landslides are still less understood than compared with deep-seated landslides (DSLs) (106 to $107 \mathrm{m3}$ ) (Pollet 2004) and we still have to learn how certain DSGSD affect the overall geomorphological evolution of landscapes.

Several authors have linked the stability of these landslides to the long-term evolution of mountain ranges topography (e.g., rock uplift, exhumation rates, and river incision) (Bovis 1982; Crosta and Zanchi 2000; Agliardi et al. 2001; Ballantyne 2002a, b; Korupet al. 2007; Larsen et al. 2010; Larsen and Montgomery 2012; Blöthe et al. 2007; Larsen et al. 2010; Larsen and Montgomery 2012; Blöthe et al. 2015). The localization of DSGSD is strongly controlled by the structural inheritance, the topographic constraints (Radbruch-Hall 1978; Varnes et al. 1990), and the geology (Jomard 2006; El Bedoui et al. 2009; Zerathe and Lebourg 2012). It is also recognized that the seismic activity can control the destabilization or the reactivation of DSGSD (e.g., Beck 1968; Harp and Jibson 1996; McCalpin and Hart 2003; Gutiérrez-Santolalla et al. 2005; Hippolyte et al. 2006; Gutiérrez et al. 2008).

Many DSGSDs in the Alps were triggered in the Holocene period (Tibaldi et al. 2004; Hippolyte et al. 2006; Agliardi et al. 2009; Hippolyte et al. 2009; Pánek et al. 2011; Hippolyte et al. 2012; Jomard et al. 2014) due to valley incision (Bovis and Evans 1996) and flank decompression related to glacier melting (Agliardi et al. 2001; Hippolyte et al. 2006, 2009; Agliardi et al. 2009; Crosta et al. 2013). Some of the largest examples of DSGSDs are in the Alps, like the Flims landslide (8.5 ka) (volume = 8.5-12 109 m3) (Stead and Wolter 2015), or the Sierre landslide (9.6 ka) (volume = $1.5109 \mathrm{m3}$ ) (Pedrazzini et al. 2013). In the central Italian Alps, Frattini et al. (2018), b) highlight by synthetic aperture radar (SAR) interferometry that a majority of the DSGSDs in the region are still active at present. Due to the glaciation/deglaciation cycles, it remains difficult to observe much older DSGSD in the Alps.

The glaciation/deglaciation cycles are not the only events that can trigger DSGSD. Indeed, at present time, Hou et al. (2014) concluded that the primary destabilizing factors of DSGSDs of the Kii Valley in Western Japan are (1) the degradation of rock masses and (2) the incision of the Yoshino River at the bottom of the slope. The incision alone is insufficient to trigger the slide. Furthermore, Tsou et al. (2015) found a relationship between the incision and the development of DSGSD in the mountains crossed by the Dahan River in Northern Taiwan. These observations are also present in the Mediterranean area; Buccolini et al. (2010) and Gargani et al. (2014) highlight the link between marine regressions and slope destabilization resulting from valley incision. This work demonstrates the importance of the valley incision factor in the establishment of DSGSDs.

Still in the Mediterranean area, the Messinian Salinity Crisis (MSC) represents the most relevant valley incision events that ever occur in the region (Clauzon 1979; Clauzon 1982; Lofi et al. 2005; Maillard et al. 2006; Bertoni and Cartwright 2007; Cornée et al. 2008). This eustatic event was characterized by an almost complete desiccation of the Mediterranean Basin after its disconnection from the Atlantic Ocean at $5.97 \mathrm{Ma}$ (Krijgsman et al. 1999). The Messinian Salinity Crisis (MSC) lasted from 5.97 to $5.46 \mathrm{Ma}$ (Gautier et al. 1994; Clauzon et al. 1996a; Krijgsman et al. 1999; Bache et al. 2012; Manzi et al. 2013) but the sea level drops down by about $1500 \mathrm{~m}$ compared with present levels 
(Gorini et al. 2005) only at 5.6 Ma (Clauzon et al. 1996a). Every river connected to the Mediterranean Sea underwent intense incisions from regressive erosion that penetrated inland in order to adjust to the new base level. Incision rates of up to $10 \mathrm{~mm} /$ year have been observed in certain parts of the Rhône (Loget et al. 2006). In France, we observe strong and steep incisions in the principal Mediterranean rivers, the Rhône (Gorini et al. 2005; Lofi et al. 2005; Mocochain et al. 2006), the Durance (Clauzon 1979; Hippolyte et al. 2011), and the Var (Clauzon 1978; Savoye and Piper 1991). The conditions encountered during the MSC are therefore suitable for the establishment of large-scale gravity deformations along the Messinian Canyons. The end of the MSC is marked by the flooding of the Mediterranean Sea which may have been very fast, ranging from a thousand years (Hsü et al. 1973) to only 36 years (Blanc 2002), or may also have occurred in several episodes with different filling speeds more spread over time (Bache et al. 2012). During this flooding, the Messinian Canyons were transformed into deep rias that were filled by sediments prograding in Gilbert-type fan deltas (Clauzon 1990).

In this paper, we present a new case study, the Sinne Valley DSGSD in the lower Var Valley one of the largest mass movements $(\approx 10.109 \mathrm{~m} 3)$ but especially one of the oldest in the European Alps (5.6 Ma). The particularity of this Alpine DSGSD is that it has not been triggered by the glaciation/deglaciation cycles but by the creation of the Var Canyon during the MSC. With the help of topographic and geologic analyses, and field observations, we have identified several geological and geomorphological features linked to large-scale gravitational deformation related to alpine orogenesis and canyons creation during Messinian Salinity Crisis. Finally, we describe the complete evolution of an onshore Alpine DSGSD triggered by the MSC.

\section{II- Geological setting}

The study area is in the lower Var Valley in the southern Western Alps in the Alpes-Maritimes department (southeast France). The Var River is the largest river of the Alpes-Maritimes; it is $114 \mathrm{~km}$ long and its catchment area extends on about $2600 \mathrm{~km} 2$. The lower Var Valley is defined as the Var sedimentary basin composed of Pliocene conglomerate that filled the Var Messinian Canyon (Fig. 1 and Fig. 2) created during the MSC. This territory includes the southernmost mountain range of the French Alps resulting from two main thrusts: The Castellane arc to the West and the Nice arc to the East (Fig. 1 ). These two mountain ranges are the outcomes of the exhumation of the Argentera-Mercantour Massif (Fig. 1) during the Miocene and Pliocene (Laurent 1998) and are composed of Mesozoic to Cenozoic folded sedimentary rocks. The regional slope created during this exhumation allows the series to be detached from the crystalline basement via the Keuper level (Upper Triassic), a geological formation that acted as the "soap layer" (Sanchez 2010). From bottom to top, this geological layer is composed of white dolomites interbed with varicolored marls and plastic clays, cargneules, large dolomites, and gypsum layers (Dardeau 1983). The Keuper formation has weak mechanical properties that localize deformation (Young E modulus $\approx 40 \mathrm{GPa}$ and compressive stresses $\sigma \mathrm{c} \approx 36 \mathrm{MPa}$, Fabre and Dayre 1982) (Fig. 2). The Castellane and Nice arcs did not evolve synchronously. The southern branch of the Castellane arc is essentially a Miocene structure (Clauzon 1978; Laurent et al. 2000) with a frontal thrust over the Tortonian formation (Miocene) (Irr 1984) (Fig. 2), while the Nice arc shows evidence of Late Neogene thrusting orogeny (Late Pliocene to Early Quaternary) (Clauzon 1978). Still both units underwent the same regional Quaternary uplift.

This study focuses on the Carros and Gattières areas in the Castellane arc (Fig. 2) where we observed geomorphological and geological anomalies.

The main tectonic structures resulting from the thrusting of the Castellane arc are strike-slip fault, oriented $\mathrm{N} 20-40^{\circ}$ and dipping $80-90^{\circ}$ toward the SE that moved with a sinistral horizontal sense (Fig. 2a). In the Alps, Ambrosi and Crosta (2006) demonstrated a relation between major structural features and DSGSDs. In the Marbrières Range of the Castellane arc (20 km eastward), Zerathe and 
Lebourg (2012) observed abnormal vertical shifts and typical gravitational morpho structures on a major $\mathrm{N} 20-40^{\circ}$ fault, which suggest the presence of a general gravitational reactivation of the network of inherited faults, with reactivation evolving to scarps or trenches. The lower Var Valley runs through a Gilbert-type fan delta that includes marine bottomset and foreset beds (Clauzon et al. 1990), named "conglomerate of the Var delta" (Dubar 2012) who filled most of the Messinian Var Canyon (Fig. 2). Seismic profiles show that the incision of the Var could be large, since the Messinian Erosional Surface is at $900 \mathrm{~m}$ depth near the present coast (Savoye and Piper 1991). To the north, the deep Messinian incision is still attested by 100 -m-thick marine Pliocene conglomeratic foreset beds at Clans, more than $30 \mathrm{~km}$ upstream from the present coast (Vernet 1982; Clauzon et al. 1996b).

The upper part of the western slope of the Var Valley, the Castellane arc, consists of subhorizontal Jurassic limestone (dip $\approx 5-20^{\circ}$ ) lying on deformed and thick $(>200 \mathrm{~m}$ ) Triassic formation (Fig. 2c). The presence of the Keuper evaporate makes the leading edge of the Castellane thrust extremely favorable for large landslides (DSGSD, DSL) (Zerathe 2013). Indeed, the Jurassic limestone is above plastic rocks, vulnerable to the dissolution because of the gypsum. The other outcropping main unit is thick $(\approx 200 \mathrm{~m}$ ) Miocene formation dated from middle Aquitanian to Burdigalian and composed of sandy and micaceous marls (Fig. 2). This formation is representative of a shallow sea depositional environment (Ginsburg et al. 1980).

This last main sedimentary unit is the Carros breccia (late Miocene to early Pliocene in age) a consolidated breccia deposited all along the hill slope and described only in this area (Fig. 2). This breccia lies unconformably on Jurassic and Miocene formations (Fig. 2) (Guglielmi 1993; Ginsburg et al. 1980) and in the upper levels, microbreccias and marl interbeds have been found, revealing Pliocene marine microfauna (Guebhardt 1903).

Finally, a large part of the area is covered with Quaternary scree deposits on steep slopes. Most of these slope deposits are consolidated and covered by vegetation (Ginsburg et al. 1980).

There is no glacial evidence in the southern part of the middle Var Valley. The nearest moraine deposits are located more than 20 km north of the study area (Fig. 2) (Julian 1980; Maisch et al. 1999; Jorda et al. 2000; Darnault et al. 2012). The region presents several DSLs like the La Marbriére Landslide dated from 400 ka triggered by inherited geological anisotropy, and 6 dated from 4.2 ka, triggered by intense climatic events (Zerathe 2013). In terms of regional seismicity, Larroque (2009) shows that the faults of the area can produce earthquakes with magnitude up to 7 . This magnitude is enough to trigger DSLs within a $100 \mathrm{~km}$ of the epicenter (Keefer 1994; Tibaldi et al. 1995; Jibson et al. 2004, 2006) and can have an impact on DSGSD (Moro et al. 2007).

\section{III- Methods}

We based our analysis on the combined use of GIS and field observations. Digital Terrain Model (DTM) and vectorized 1/ 50000 geological map (BD Charm-50 produced by the BRGM available at http://www.geocatalogue.fr/Detail.do?id=4156 (last accessed on 29/01/2019) analyses are used to perform large-scale geomorphological observations followed by more precise field surveys. The field surveys can confirm, disprove, or detail specific features with the help of GNSS locations, photos, and dip measurements.

The DTM used in this paper is provided by the Conseil departmental des Alpes-Maritimes (available at https: //trouver.datasud.fr/dataset/modeles-numeriques-de-terrain-go-06 (last accessed on 29/01/2020)) with a resolution of $5 \mathrm{~m}$. DTM does not consider the vegetation and can cover the entire department; it allows a spatial 3D representation of the study area through 3D view and elevation profiles and allows many observations that are not possible in the field.

Slope, surface roughness, aspect, hill shades, and curvature are used to describe morphological features like major and minor scarps, ridges and cracks, and landslides boundaries (Morelli et al. 2018). Slope, aspect, hill shades, and curvatures are estimated in ArcGIS 10.3 (Esri, Redlands, CA, USA) using 
the spatial Analyst extension, and the surface roughness is estimated at QGIS 2.18 (QGIS development Team 2019) using the Raster Terrain Analysis Plugin. Since slope and surface roughness present the best contrasts in the analysis of DTM data, particularly for escarpments, these two were performed on this study. According to Burrough and McDonnell (1998), the slope is calculated at a given cell by comparing the altitude to its neighbors $(3 \times 3$ cells), and it represents the maximal variation rate of altitude (from $0^{\circ}$ to $90^{\circ}$ ). According to Riley et al. (1999), the surface roughness is estimated in each cell by calculating the sum change in the altitude of its neighbor ( $3 \times 3$ cells) (flat area has a value close to 0 ).

Elevation profiles are realized with the QGIS DTM surface plugin Profile tool (developed by Jurgiel et al.). 3D views of the area are realized with the QGIS plugin Qgis2threejs (developed by Akagi), who combine DTM data and images of other data like geology, orthophotos, or surface roughness. Finally, the r.volume model of GRASS plugin (Hinthorne 1988 updated to GRASS 7 by Landa) is used to calculate the volume of the DSGSD resulting from the DTM and the surface area of the DSGSD.

\section{IV-Results}

\section{1) The Sinne Valley}

The Sinne Valley is a deep valley $(\approx 100 \mathrm{~m})$ perched at $700 \mathrm{~m}$ high with no permanent watercourses. Its $\mathrm{N} 20-40^{\circ}$ orientation and the presence of a strike-slip fault (Fig. 2) point out to a tectonic origin. This family of strike-slip faults is linked to the thrusting of the Castellane arc and ceased their activity in late Miocene.

A set of different gaps or crevasses, 1 to $2 \mathrm{~m}$ wide and 1 to $3 \mathrm{~m}$ deep, all-oriented $\mathrm{N} 20-40^{\circ}$ and tracked on about $100 \mathrm{~m}$ was also observed in the Sinne Valley showing NW-SE extension (Fig. 3c).

The Sinne Valley is bordered by two plateaus, one to the east and the other to the west over a distance of $\approx 1.5 \mathrm{~km}$ (Fig. $2 \mathrm{c}, \mathrm{b}$ and Fig. 3b). These two plateaus are composed of the same rocks, the Portlandian and Berriasian lithographic limestone (Fig. 2b, Fig. 3b). We measured bedding planes of the Jurassic formation. On the western plateau, they strike from 205 to $255^{\circ}$ and dip from $5^{\circ}$ to $20^{\circ}(14$ measurements) (Fig. 3e). They are consistent with those of Baggioni (1971) who described the formation of the summit as sub-horizontal including the plateaus. The bedding planes at the lower part of the Jurassic formation of the Carros/Gattières hill slope strike from $175^{\circ}$ to $205^{\circ}$ and dip from $25^{\circ}$ to $40^{\circ}$ (8 measurements) (Fig. 3e). These are consistent with those of Zerathe (2013) (Fig. 3a). Using the DTM and a stochastic approach that traces ten topographic profiles passing through the two plateaus (profiles $\pm N W$-SE), it appears that the eastern plateau bordering the Sinne Valley has an average elevation of $925 \pm 15 \mathrm{~m}$, while the western plateau has an average altitude of $1015 \pm 6 \mathrm{~m}$, with a difference of approximately $90 \pm 10 \mathrm{~m}$ (Fig. 3b). In addition, we perform an analysis on the geological map combine with the DTM and a $30 \mathrm{~m}$ stratigraphic offset is observed in the Portlandian- Berriasian (J7), Kimmeridgian (J6), and Sequanian (J5) layers (Fig. 3b). With an approximate $10^{\circ}$ dip (Fig. 3b), the offset of the Jurassic series across the valley can be estimated at about $70-80 \mathrm{~m}$, which is close to the $90 \mathrm{~m}$ offset between the two plateaus.

We infer that the shape of the Sinne Valley can be assimilated with a "double-crested ridge" (Fig. 3b), a geomorphological structure characteristic of DSGSDs (Agliardi et al. 2012).

\section{2) The Carros breccia}

Along the Var Valley, the Carros breccia is only present in the Carros/Gattières area and corresponds to a thick and highly consolidated slope formation. According to the Roquesteron Geological Map (Ginsburg et al. 1980), the Carros breccia was deposited both at the front of the Castellane thrust and at the edge of the Var Messinian Canyon. Gèze and Nestéroff (1968) described the breccia as synorogenic when the Castellane arc was emplaced. But Clauzon (1978) pointed out that at Le Broc borehole (from 98 to -12 m elevation) (Fig. 2b), the Carros breccia is at least $70 \mathrm{~m}$ thick 
(from - 12 to $57 \mathrm{~m}$ elevation), and is overlain by Pliocene marls (from 57 to $68 \mathrm{~m}$ elevation) and Holocene alluvium (from 68 to $98 \mathrm{~m}$ elevation). He concluded that the breccia results from the Messinian incision of the Var River, and is not a syn-tectonic breccia because it postdates the emplacement of the Castellane arc. At Le Broc (Fig. 2), we observed northeast prograding subaqueous foreset beds of debris (Fig. 4a) with marine burrows on the limestone blocks (Fig. 4b) which confirms that the breccia continued to deposit after the flooding of the lower Var Valley at the end of the MSC. At present days, the outcropping surface of the Carros breccia is $3.8 \mathrm{~km} 2$, with an approximate thickness of $70 \mathrm{~m}$ (i.e., le Broc borehole) and it represents $2.7 \times 108 \mathrm{~m} 3$. This volume is an underestimation since the Pliocene conglomerate of the Var delta and Holocene formation may cover it (i.e., le Broc borehole). Anyway, this formation indicates that the western slope of the Var Valley has been locally subject to high degradation during and after the Messinian incision.

\section{3) The DSLS}

According to El Bedoui et al. (2009), Hradeck and Pánek (2008), and Jomard et al. (2014), DSGSDs may induce rapid localized failure events like DSLs especially on the slope toe; this interaction can be explained by the long-term deformations of DSGSDs and the resulting steepening of the slopes. Zerathe (2013) already documents a DSL in the area: the Gattières DSL (1 Fig. 2b, Fig. 3a). This DSL has an estimated volume of $1.5 \times 106 \mathrm{~m} 3$ and a surface of $0.08 \mathrm{~km} 2$.

On a three-dimensional view of the roughness of the area (Fig. 3e), we can distinguish the presence of three triangular facets on the slope. According to Strak (2012), this geomorphological structure is representative of active normal faults, the southernmost triangular facet corresponding to Gattières DSL (Fig. 3a). This analysis was followed by field campaigns confirming the presence of a fault represented by a scarp that extends for about $2 \mathrm{~km}$ of length along the hill slope (Fig. 3e). This escarpment has many karstification indices with many concretions of speleothems covering the whole surface in some places and various evidences of deformation like NW-SE extensional crevasses of different sizes (Fig. 3d). Field campaigns, DTM analysis, and geological map analyses have enabled us to define that the Gattières DSL and two other DSLs are linked to the triangular facets and the socalled Gattières/Carros fault, the Ripert DSL (Fig. 2 and Fig. 3e with a volume estimated at $1.8 \times 106 \mathrm{~m} 3$ ) and the Carros DSL (Fig. 2 and Fig. 3e with a volume estimated at $1 \times 107 \mathrm{m3}$ ). Due to their lengths and shapes, the Gattières/Carros fault and the DSLs are very likely due to the DSGSD. DSGSD activity can create faults along the hill slope to accommodate the deformation, and the fault and the inward dip of the Jurassic formation contribute to fluid circulation to the Triassic gypsum formation whose dissolution leads to the subsidence of the massif and more unstable conditions.

According to Zerathe et al. (2014), who performed cosmic ray exposure dating (CRE) on six DSLS of the region, including the Gattières DSL, their triggers are dated around 4 ka. These datings are correlated with the 4.2 ka climate events, an intense paleohydrological pulse in the Mediterranean area (Zanchetta et al. 2016). These datings correlate the triggering of the DSLs with intense and major climatic events, we will consider that in the absence of such events and of recent deformations observed in the field, the DSLs are considered dormant or suspended.

\section{4) The Var River deviation}

The most striking geomorphological structure of the area is the deviation of the Var River toward the east over $8 \mathrm{~km}$ north-south between the towns of Gattières and Carros, with a maximum shift of 1 to $2 \mathrm{~km}$ toward the east (Figs. 2b, c and 3). Several authors agree that the Var took a much NS straighter course in the lower Var Valley during the MSC (Savoye and Piper 1991; Clauzon 1975; Dubar 2012). We propose that this deviation is related to the DSGSD of the Sinne Valley. This hypothesis is supported by the long-term evolution of the DSGSD and DSLs, which have continuously 
brought large quantities of gravity materials (i.e., Carros breccias, $2.7 \times 108 \mathrm{~m} 3$ ) to the right bank slope of the Var Valley from the Messinian Canyon to its Pliocene infill.

\section{5) Evolution of the Sinne Valley DSGSD}

During the late Miocene period, the front of the Castellane arc overlapped the Miocene formations. The Keuper was overthickened because of thrusting and the Jurassic formations resting on the Triassic were titled northward by about $5-20^{\circ}$ and acquired the present inward dip (Fig. $5 \mathrm{~A}$ ). The overlap phase formed a N20- 40 strike-slip fault that contributes to the tectonic deformation in the region (Fig. 2, Fig. 5).

During the MSC when the canyon reached a certain depth (at present the canyon is approximately $300 \mathrm{~m}$ depth in the study area), slope-undermining phenomena and constraints applied to the right flank of the slope took advantage of the major tectonic fault in the Sinne Valley-a highly altered zone-thus triggering the DSGSD and the related normal faults to accommodate the deformation (Fig. 5B). The Keuper evaporites and clays may have played an important role in the setting up and dynamics of these landslides (DSGSD and DSLs). The counter dip of the Jurassic layers promotes fluid circulation inside the massif, while the normal faults are weakness areas that promoted deep water circulation (Barton et al. 1995) within the Keuper evaporites. The fluid circulation could lead to the dissolution of the gypsum layers and the modification of the mechanical properties of the clay layers of the Keuper Formation, with both phenomena being related to the diminution of stability (Baron et al. 2004; Guerrero et al. 2004; Azañón et al. 2005, 2010; Gutiérrez et al. 2012).

The DSGSD may have proceeded at a very low speed over thousands of years, but the constraint applied to the hill slope was large enough to produce numerous DSL-type landslides, thus allowing the deposition of the Carros breccia during the late Messinian incision (Fig. 5B). Moreover, the crevasses in the Sinne Valley are the result of this activity and that demonstrates that the NW-SE extension was able to develop deep in the Jurassic formations.

These constraints continued during the marine flooding of the Var Valley at the end of the MSC when the Var Canyon was transformed to Ria. At the same time, the exhumation of the ArgenteraMercantour stopped, marking the end of the Castellane arc activity (Fig. 5C). The flooding of the lower Var Valley probably triggered a second phase of activity for the DSGSD and DSLs presented in Fig. 6 by increasing the pore water pressure and thus destabilizing the slopes. This effect may have been greatly accentuated when the water sea level reached the Keuper Formation (Fig. 5C) due to the clay and gypsum rocks being highly vulnerable to the presence of water.

In the Var Valley, the marine conglomeratic foreset beds indicate the elevation of the sea level during the Pliocene. Because the Alps and their foreland have been uplifted since the Pliocene, Pliocene marine deposits are present at various elevations. Despite Quaternary erosion, the Pliocene marine conglomerate at Carros is still present up to $350 \mathrm{~m}$ elevation, which is a minimum for the elevation of the Pliocene sea level at this place. At Aspremont, on the eastern flank of the Var Valley, marine conglomeratic foreset beds are present up to $650 \mathrm{~m}$ elevation. These elevations are partly due to local tectonic deformation, but they show that Pliocene flooding could have reached the elevation of the thrust detachment in the Keuper formation.

Thus, during the deposition of the Var conglomerate and the Pliocene high stand phase (Fig. 5C) in the lower Var Valley, we assume that the DSGSD and DSLs experienced sustained gravitational activity and brought large numbers of slope breccias to the foreset beds of the Pliocene Gilbert-type delta (Fig. 5C). With the progressive filling of the Messinian Canyon by Gilbert-type delta, the DSGSD had a more stable condition since the thick conglomerate acted as a buttress. We do not know when the DSGSD activity stopped, but we assume that the activity of geomorphological structures with deformations such as crevasses (Fig. 3) has ended before $1.7 \mathrm{Ma}$. 
At present, the DSGSD in the Sinne Valley is still in place, due not only to its size but also to the post-Miocene uplift of about $280 \mathrm{~m}$ in the Castellane arc and the quaternary incision of the Var River. An estimation of the DSGSD's volume by the r.volume plugin gives $9.5109 \mathrm{~m} 3 \mathrm{from}$ the Sinne Valley to the Miocene formations (Fig. 5D). The gravitational material resulted from the DSGSD and DSL activity represented by the Carros breccia (estimated at $2.7108 \mathrm{~m} 3$ at present days) was an obstacle to the flowing of the Var River during the regional uplift (Fig. 5C) (Clauzon 1996; Schroëtter 1997). This hypothesis of a deviation of the Var River owing to the contribution of gravitational material from the slope is in agreement with the presence of the DSGSD and DSLs. There are no active evidences of deformations observe for the DSGSD and the crevasses on the Sinne Valley were most likely exhumed by erosion. There is also no evidence of active deformations for the three DSLs and the regional dynamics observed by Zerathe et al. (2014) imply major climate events for their triggering so in the current state DSLs are considered dormant.

Since there is no evidence of any deformations link to the DSGSD or the three DSLs, we did not perform any activity measurement in the area. The combination of $5 \mathrm{~m}$ resolution DTM analysis and field checking seems to be suitable in particular for the detection of escarpments, which are highlighted by roughness measurements especially over an area of more than $20 \mathrm{~km} 2$. This technique could easily be applied to the entire front of the Castellane arc to highlight escarpments that could be linked to DSLs. Moreover, due to the unfavorable topography and the land use on the overall slope, it was not possible to set up geophysical profiles such as electrical resistivity tomography (ERT) profiles or seismic reflection profiles. Those techniques would have allowed us to confirm or disproved, and visualized, the presence of the gravity faults highlighted in this paper instead of just relying on the DTM analyses.

\section{IV- Conclusion}

In this study, we highlight that the lower Var Valley records gravitational deformations since 5.6 Ma. We provided several arguments in favor of the presence of a DSGSD of about 10 billion m3, the largest and the oldest landslide in the front of the Castellane arc and in the Alpes-Maritimes department.

This DSGSD results from a gravitational process that occurred during the MSC when the Mediterranean Sea level dropped of about $1500 \mathrm{~m}$ (compared with present levels) and induced the incision of the Messinian Var Canyon that later was filled by conglomerates during the Pliocene (Fig. 5).

This deformation affected the entire massif and allowed the establishment of DSLs (Carros, Gattières, and Ripert) which actively participated in the creation of the Carros breccia.

The proposed evolution of the DSGSD follows the events that influenced the lower Var Valley over millions of years and explains in a coherent way the various observations and geomorphological characteristics found at present including the Sinne Valley, the Carros breccia, and the Var River deviation.

Landslides and collapse processes are used to be studied in recent times with active signs of deformations but at present days, there is no evidence of DSGSD or DSLs activities in the area. However, in this work, we show that it is possible to observe very old stigmas of collapse protected from erosion by their size with a dynamic driven by tectonic and gravitational events.

Acknowledgments: We thank all the regions that make up this program. We also thank Loïc Santino for his support.

Funding information : This study was financially supported by the Interreg-Alcotra-AD-VITAM project. 


\section{References :}

Agliardi F, Crosta G, Zanchi A (2001) Structural constraints on deep-seated slope deformation kinematics. Eng Geol 59:83-102. https://doi.org/10.1016/\$0013-7952(00)00066-1

Agliardi F, Crosta GB, Zanchi A, Ravazzi C (2009) Onset and timing of deep-seated gravitational slope deformations in the eastern Alps, Italy. Geomorphol, Dating, Trigger, Model Hazard Assess Large Landslides 103:113-129. https://doi.org/ 10.1016/j.geomorph.2007.09.015

Agliardi F, Crosta GB, Frattini P (2012) Slow rock-slope deformation. In: Clague J-J, Stead D (eds) Landslides: types, mechanisms and modeling, pp 209-221

Ambrosi C, Crosta GB (2006) Large sackung along major tectonic features in the Central Italian Alps. Eng Geol Large Landslides: Dating, Trigger, Model Hazard Asses 83:183- 200. https://doi.org/10.1016/j.enggeo.2005.06.031

Azañón JM, Azor A, Pérez-Peña JV, Carrillo JM (2005) Late Quaternary large-scale rotational slides induced by river incision: the Arroyo de Gor area (Guadix basin, SE Spain). Geomorphology 69:152-168

Azañón JM, Azor A, Yesares J, Tsige M, Mateos RM, Nieto F, Delgado J, López-Chicano M, Martín W, Rodríguez-Fernández J (2010) Regionalscale high-plasticity clay-bearing formation as controlling factor on landslides in Southeast Spain. Geomorphology 120:26-37

Bache F, Popescu S-M, Rabineau M, Gorini C, Suc J-P, Clauzon G, Olivet J-L, Rubino J-L, Melinte-Dobrinescu MC, Estrada F, Londeix L, Armijo R, Meyer B, Jolivet L, Jouannic G, Leroux E, Aslanian D, Reis ATD, Mocochain L, Dumurdžanov N, Zagorchev I, Lesić V, Tomić D, Namık Çağatay M, Brun J-P, Sokoutis D, Csato I, Ucarkus G, Çakır Z (2012) A two-step process for the reflooding of the Mediterranean after the Messinian Salinity Crisis. Basin Res 24:125-153. https://doi.org/10.1111/j.1365-2117.2011.00521.x

Baggioni M (1971) Etude morphologique de la rive droite de la Basse Vallée du Var. Méditerranée 2:785-801. https://doi.org/10.3406/medit.1971.1406

Ballantyne CK (2002a) A general model of paraglacial landscape response. The Holocene 12:371-376. https://doi.org/10.1191/0959683602hl553fa

Ballantyne CK (2002b) Paraglacial geomorphology. Quat Sci Rev 21:1935-2017. https:// doi.org/10.1016/S0277-3791(02)00005-7

Baron I, Cílek V, Krejci O, Melichar R, Hubatka F (2004) Structure and dynamics of deepseated slope failures in the Magura Flysch Nappe, outer Western Carpathians (Czech Republic). Nat Hazards Earth Syst Sci 4:549-562

Barton CA, Zoback MD, Moos D (1995) Fluid flow along potentially active faults in crystalline rock. Geology 23:683-686. https://doi.org/10.1130/0091- 7613(1995)023<0683:FFAPAF>2.3.CO;2

A C B (1968) Gravity faulting as a mechanism of topographic adjustment. N Z J Geol Geophys 11:191-199. https://doi.org/10.1080/00288306.1968.10423684

Bertoni C, Cartwright JA (2007) Major erosion at the end of the Messinian Salinity Crisis: evidence from the Levant Basin, Eastern Mediterranean. Basin Res 19:1-18. https:// doi.org/10.1111/j.1365-2117.2006.00309.x

Blanc P-L (2002) The opening of the Plio-Quaternary Gibraltar Strait: assessing the size of a cataclysm. Geodin Act a 15:303-317. https ://doi. org/10.1080/ 09853111.2002.10510763

Blöthe JH, Korup O, Schwanghart W (2015) Large landslides lie low: excess topography in the Himalaya-Karakoram ranges. Geology 43:523526. https://doi.org/10.1130/ G36527.1

Bovis MJ (1982) Uphill-facing (antislope) scarps in the Coast Mountains, southwest British Columbia. GSA Bull 93:804-812. https://doi.org/10.1130/0016- 7606(1982)93<804:UASITC>2.0.CO;2

Bovis MJ, Evans SG (1996) Extensive deformations of rock slopes in southern Coast Mountains, southwest British Columbia, Canada. Eng Geol 44:163-182. https:// doi.org/10.1016/S0013-7952(96)00068-3

Buccolini M, Gentili B, Materazzi M, Piacentini T (2010) Late Quaternary geomorphological evolution and erosion rates in the clayey periAdriatic belt (Central Italy). Geomorphology 116:145-161. https://doi.org/10.1016/j.geomorph.2009.10.015

Burrough PA, McDonnell RA (1998) Principles of geographical information systems. Oxford University Press, New York

Clauzon G (1975) Preuves et implications de la régression endoréique messinienne au niveau des plaines abyssales: I'exemple du Midi méditerranéen français. Bulletin de l'Association de Géographes Français 52:317-333 
Clauzon G (1978) The Messinian Var canyon (Provence, Southern France) - paleogeographic implications. Mar Geol Messinian Erosional Surf Mediterranean 27:231-246. https://doi.org/10.1016/0025-3227(78)90033-6

Clauzon G (1979) Le canyon messinien de la Durance (Provence, France): Une preuve paléogéographique du bassin profond de dessiccation. Palaeogeogr Palaeoclimatol Palaeoecol 29:15-40

Clauzon G (1982) Le canyon messinien du Rhone; une preuve decive du "desiccated deep-basin model”(Hsue, Cita and Ryan, 1973). Bulletin de la Société Géologique de France 7:597-610

Clauzon G (1990) Restitution de l'évolution géodynamique néogène du bassin du Roussillon et de l'unité adjacente des Corbières d'après les données écostratigraphiques et paléogéographiques. Paléobiologie Continentale 17:125-155

Clauzon G (1996) Limites de séquences et évolution géodynamique/Sequence boundaries and geodynamic evolution. Géomorphologie : Relief, Processus, Environ 2:3-21. https://doi.org/10.3406/morfo.1996.867

Clauzon G, Suc JP, Aguilar JP, Ambert P, Cappetta H, Cravatte J, Drivaliari A, Domenech R, Dubar M, Leroy S (1990) Pliocene geodynamic and climatic evolutions in the French Mediterranean region. Iberian Neogene Basins:131-186

Clauzon G, Rubino JL, Suc JP, Zhang Z (1996a) Les rias pliocènes du Var et de Ligurie: comblement sédimentaire et évolution géodynamique. Livret guide-Excursion commune du Groupe Français d'Etude du Néogène et du Groupe Français de Géomorphologie

Clauzon G, Suc J-P, Gautier F, Berger A, Loutre M-F (1996b) Alternate interpretation of the Messinian salinity crisis: controversy resolved? Geology 24:363-366. https:// doi.org/10.1130/0091-7613(1996)024<0363:AIOTMS>2.3.CO;2

Cornée J-J, Maillard A, Conesa G, Garcia F, Saint Martin J-P, Sage F, Münch P (2008) Onshore to offshore reconstruction of the Messinian erosion surface in Western Sardinia, Italy: implications for the Messinian salinity crisis. Sediment Geol 210:48- 60. https://doi.org/10.1016/j.sedgeo.2008.06.005

Crosta G, Zanchi A (2000) Deep seated slope deformations: huge, extraordinary, enigmatic phenomena. In: Landslides in research, theory and practice: Proceedings of the 8th International Symposium on Landslides Held in Cardiff on 26-30 June 2000. Thomas Telford Publishing, pp 1 351

Crosta GB, Frattini P, Agliardi F (2013) Deep seated gravitational slope deformations in the European Alps. Tectonophysics 605:13-33

Dardeau G (1983) Le Jurassique des Alpes-Maritimes (France): stratigraphie, paléogéographie, évolution du contexte structural à la jonction des dispositifs dauphinois, briançonnais et provençal. Université Nice Sophia Antipolis

Darnault R, Rolland Y, Braucher R, Bourlès D, Revel M, Sanchez G, Bouissou S (2012) Timing of the last deglaciation revealed by receding glaciers at the Alpine-scale: impact on mountain geomorphology. Quat Sci Rev 31:127-142

Dubar M (2012) Les dépôts pliocènes et pléistocènes de la basse vallée du Var (Nice, Alpes-Maritimes): variations du niveau marin et néotectonique depuis 5 millions d'années. Ann Mus Hist Nat Nice 26:35-54

El Bedoui S, Guglielmi Y, Lebourg T, Pérez J-L (2009) Deep-seated failure propagation in a fractured rock slope over 10,000 years: the La Clapière slope, the south-eastern French Alps. Geomorphology 105:232-238

Fabre D, Dayre M (1982) Proprietes geotechniques de gypses et anhydrites du trias des alpes de savoie (France). Bull Int Assoc Eng Geol 25:91-98. https://doi.org/10.1007/BF02603198

Frattini P, Crosta GB, Rossini M, Allievi J (2018) Activity and kinematic behaviour of deepseated landslides from PS-InSAR displacement rate measurements. Landslides 15:1053-1070. https://doi.org/10.1007/s10346-017-0940-6

Gargani J, Bache F, Jouannic G, Gorini C (2014) Slope destabilization during the Messinian salinity crisis. Geomorphology 213:128-138

Gautier F, Clauzon G, Suc J-P, Cravatte J, Violanti D (1994) Age et durée de la crise de salinité messinienne. Comptes rendus de l'Académie des sciences. Série 2. Sciences de la Terre et Des Planètes 318:1103-1109

Gèze B, Nestéroff W (1968) Notice explicative, carte géol. France (1/50 000), feuille Menton-Nice, Orléans

Ginsburg L, Montenant C, Baudron JC, Alziar G (1980) Carte géologique de France au /150000e, n972. feuille de Roquesteron

Gorini C, Lofi J, Duvail C, Dos Reis AT, Guennoc P, Lestrat P, Mauffret A (2005) The Late Messinian salinity crisis and Late Miocene tectonism: interaction and consequences on

the physiography and post-rift evolution of the Gulf of Lions margin. Mar Pet Geol 22:695-712

Guebhardt A (1903) L'âge pliocène de la brèche du Broc. B.S.G.F, p 667 
Guerrero J, Gutiérrez F, Lucha P (2004) Paleosubsidence and active subsidence due to evaporite dissolution in the Zaragoza area (Huerva River valley, NE Spain): processes, spatial distribution and protection measures for transport routes. Eng Geol 72:309-329

Guglielmi Y (1993) Hydrogéologie des aquifères plio-quaternaires de la basse vallée du Var (Alpes-Maritimes, France). In: Université d'Avignon et des pays de Vaucluse

Gutiérrez F, Ortuño M, Lucha P, Guerrero J, Acosta E, Coratza P, Piacentini D, Soldati M (2008) Late Quaternary episodic displacement on a sackung scarp in the central Spanish Pyrenees. Secondary paleoseismic evidence? Geodin Acta 21:187-202

Gutiérrez F, Linares R, Roqué C, Zarroca M, Rosell J, Galve JP, Carbonel D (2012) Investigating gravitational grabens related to lateral spreading and evaporite dissolution subsidence by means of detailed mapping, trenching, and electrical resistivity tomography (Spanish Pyrenees). Lithosphere 4:331-353

Gutiérrez-Santolalla F, Acosta E, Ríos S, Guerrero J, Lucha P (2005) Geomorphology and geochronology of sackung features (uphill-facing scarps) in the Central Spanish Pyrenees. Geomorphology 69:298-314

Harp EL, Jibson RW (1996) Landslides triggered by the 1994 Northridge, California, earthquake. Bull Seismol Soc Am 86:S319-S332

Hippolyte J-C, Brocard G, Tardy M, Nicoud G, Bourlès D, Braucher R, Ménard G, Souffaché

B (2006) The recent fault scarps of the Western Alps (France): tectonic surface ruptures or gravitational sackung scarps? Combined mapping, geomorphic, levelling, and 10Be dating approach. Tectonophysics 418:255-276

Hippolyte J-C, Bourlès D, Braucher R, Carcaillet J, Léanni L, Arnold M, Aumaitre G (2009) Cosmogenic 10Be dating of a sackung and its faulted rock glaciers, in the Alps of Savoy (France). Geomorphology 108:312-320

Hippolyte J-C, Clauzon G, Suc J-P (2011) Messinian-Zanclean canyons in the Digne nappe (southwestern Alps): tectonic implications. Bulletin de la Société Géologique de France 182:111-132. https://doi.org/10.2113/gssgfbull.182.2.111

Hippolyte J-C, Bourlès D, Léanni L, Braucher R, Chauvet F, Lebatard AE (2012) 10Be ages reveal> 12ka of gravitational movement in a major sackung of the Western Alps (France). Geomorphology 171:139-153

Hou Y, Chigira M, Tsou C-Y (2014) Numerical study on deep-seated gravitational slope deformation in a shale-dominated dip slope due to river incision. Eng Geol 179:59-75

Hradeckỳ J, Pánek T (2008) Deep-seated gravitational slope deformations and their influence on consequent mass movements (case studies from the highest part of the Czech Carpathians). Nat Hazards 45:235-253

Hsü KJ, Cita MB, Rian WBF (1973) The origin of the Mediterranean evaporite. In: Rian WBF et al (eds) Initial reports of the deep sea drilling project, pp 1203-1231

Irr F (1984) Paléoenvironnements et évolution géodynamique néogènes et quaternaire de la bordure nord du bassin méditerranéen occidental: un système de pente de la paléo-marge liguro-provençal

Jibson RW, Harp EL, Schulz W, Keefer DK (2004) Landslides triggered by the 2002 Denali Fault, Alaska, earthquake and the inferred nature of the strong shaking. Earthquake Spectra 20:669-691

Jibson RW, Harp EL, Schulz W, Keefer DK (2006) Large rock avalanches triggered by the M 7.9 Denali Fault, Alaska, earthquake of 3 November 2002. Eng Geol 83:144-160

Jomard H (2006) Analyse multi-échelles des déformations gravitaires du Massif de l'Argentera Mercantour. Université Nice Sophia Antipolis

Jomard H, Lebourg T, Guglielmi Y (2014) Morphological analysis of deep-seated gravitational slope deformation (DSGSD) in the western part of the Argentera massif. A morpho-tectonic control? Landslides 11:107-117. https://doi.org/10.1007/s10346- 013-0434-0

Jorda M, Rosique T, Évin J (2000) Données nouvelles sur l'âge du dernier maximum glaciaire dans les Alpes méridionales françaises. Comptes Rendus de l'Académie des Sci-Series IIA-Earth Planet Sci 331:187-193

Julian M (1980) Les alpes maritimes franco-italiennes. etude morphologique (Thèse d’Etat thesis). Aix-Marseille II

Keefer DK (1994) The importance of earthquake-induced landslides to long-term slope erosion and slope-failure hazards in seismically active regions. Geomorphology 10:265-284

Korup O, Clague JJ, Hermanns RL, Hewitt K, Strom AL, Weidinger JT (2007) Giant landslides, topography, and erosion. Earth Planet Sci Lett 261:578-589. https:// doi.org/10.1016/j.epsl.2007.07.025 
Krijgsman W, Hilgen FJ, Raffi I, Sierro FJ, Wilson DS (1999) Chronology, causes and progression of the Messinian salinity crisis. Nature 400:652655

Larroque C (2009) Aléa sismique dans une région intraplaque à sismicité modérée: la jonction Alpes-Bassin Ligure. Université Nice Sophia Antipolis

Larsen IJ, Montgomery DR, Korup O (2010) Landslide erosion controlled by hillslope material. Nat Geosci 3:247-251

Larsen IJ, Montgomery DR (2012) Landslide erosion coupled to tectonics and river incision. Nat Geosci 5:468-473. https://doi.org/10.1038/ngeo1479

Laurent $O$ (1998) Modalités de la structuration d'un prisme de front de chaîne: L'exemple de l'arc de Castellane (Chaînes subalpines méridionales, France). École doctorale Sciences fondamentales et appliquées (Nice)

Laurent O, Stéphan J-F, Popoff M (2000) Modalité de la structuration miocène de la branche sud de l'arc de Castellande (chaîne subalpines méridionales). Géol Fr 3:33-65

Lofi J, Gorini C, Berné S, Clauzon G, Dos Reis AT, Ryan WB, Steckler MS (2005) Erosional processes and paleo-environmental changes in the Western Gulf of Lions (SW France) during the Messinian Salinity Crisis. Mar Geol 217:1-30

Loget N, Davy P, Van den Driessche J (2006) Mesoscale fluvial erosion parameters deduced from modeling the Mediterranean sea level drop during the Messinian (late Miocene). J Geophys Res: Earth Surf 111

Maillard A, Gorini C, Mauffret A, Sage F, Lofi J, Gaullier V (2006) Offshore evidence of polyphase erosion in the Valencia Basin (Northwestern Mediterranean): scenario for the Messinian Salinity Crisis. Sediment Geol 188:69-91

Maisch M, Wipf A, Denneler B, Battaglia J, Benz C (1999) Die Gletscher der Schweizer Alpen: Gletscherhochstand 1850-Aktuelle Vergletscherung-Gletscherschwund- Szenarien 21. Jahrhundert, Schlussbericht NFP31 vdf Hochschulverlag, ETH Zurich

Malgot J (1977) Deep-seated gravitational slope deformations in neovolcanic mountain ranges of Slovakia. Bulletin of the International Association of Engineering Geology- Bulletin de l'Association Internationale de Géologie de l'Ingénieur 16:106-109

Manzi V, Gennari R, Hilgen F, Krijgsman W, Lugli S, Roveri M, Sierro FJ (2013) Age refinement of the Messinian salinity crisis onset in the Mediterranean. Terra Nova 25:315-322. https://doi.org/10.1111/ter.12038

McCalpin JP, Hart EW (2003) Ridge-top spreading features and relationship to earthquakes, San Gabriel Mountains Region, Southern California: Part A. Distribution and description of ridge-top depressions (sackungen): Part B. Paleoseismic investigations of ridge-top depressions. In: Hart EW (ed) Ridge-top spreading in California. California Geological Survey, Open-File Report

Mocochain L, Clauzon G, Bigot J-Y (2006) Réponses de l'endokarst ardéchois aux variations eustatiques générées par la crise de salinité messinienne. Bull Soc Géol Fr 177:27-36

Morelli S, Pazzi V, Frodella W, Fanti R (2018) Kinematic reconstruction of a deep-seated gravitational slope deformation by geomorphic analyses. Geosciences 8:26 Moro M, Saroli M, Salvi S, Stramondo S, Doumaz F (2007) The relationship between seismic deformation and deep-seated gravitational movements during the 1997 Umbria-Marche (Central Italy) earthquakes. Geomorphology 89:297-307. https:// doi.org/10.1016/j.geomorph.2006.12.013

Pánek T, Tábořík P, Klimeš J, Komárková V, Hradeckỳ J, Št'astnỳ M (2011) Deep-seated gravitational slope deformations in the highest parts of the Czech Flysch Carpathians: evolutionary model based on kinematic analysis, electrical imaging and trenching. Geomorphology 129:92-112

Pedrazzini A, Jaboyedoff M, Loye A, Derron M-H (2013) From deep seated slope deformation to rock avalanche: destabilization and transportation models of the Sierre landslide (Switzerland). Tectonophys Slope Tectonics: Struct Slope Fail 605:149-168. https://doi.org/10.1016/j.tecto.2013.04.016

Pollet N (2004) Mouvements gravitaires rapides de grandes masses rocheuses: Apports des observations de terrain à la compréhension des processus de propagation et dépôt: Application aux cas de La Madeleine (Savoie, France), Flims (Grisons, Suisse) et Kofels (Tyrol, Autriche). École nationale des ponts et chaussées (France) QGIS.org (2020) QGIS Geographic Information System. Open Source Geospatial Foundation Project http://qgis.org

Radbruch-Hall DH (1978) Gravitational creep of rock masses on slopes, in: Developments in geotechnical engineering. Elsevier, pp. In: 607-657 Riley SJ, DeGloria SD, Elliot R (1999) Index that quantifies topographic heterogeneity. Int J Therm Sci 5:23-27

Sanchez G (2010) Chronologies et évolution de la déformation de la croute moyenne à la surface dans un prisme collisionel en décrochement: impacts sur l'aléa sismogravitaire: exemple des Alpes Sud-occidentales. Nice 
Sanchez G, Rolland Y, Schreiber D, Giannerini G, Corsini M, Lardeaux J-M (2010) The active fault system of SW Alps. J Geodyn 49:296-302 Savoye B, Piper DJ (1991) The Messinian event on the margin of the Mediterranean Sea in the Nice area, southern France. Mar Geol 97:279304

Schroëtter JM (1997) L'enregistrement sédimentaire de la déformation mio- plioquaternaire sur la bordure ouest de l'arc de Nice: analyse sédimento-morphostructurale. D.E.A. Univ, Nice $21 \mathrm{p}$

Stead D, Wolter A (2015) A critical review of rock slope failure mechanisms: the importance of structural geology. J Struct Geol 74:1-23. https://doi.org/10.1016/j.jsg.2015.02.002

Strak V (2012) L'évolution du relief le long des escarpements de faille normale active : observations, modélisations expérimentales et numériques (phdthesis). Université Pierre et Marie Curie - Paris VI

Tibaldi A, Ferrari L, Pasquarè G (1995) Landslides triggered by earthquakes and their relations with faults and mountain slope geometry: an example from Ecuador. Geomorphology 11:215-226

Tibaldi A, Rovida A, Corazzato C (2004) A giant deep-seated slope deformation in the Italian Alps studied by paleoseismological and morphometric techniques. Geomorphology 58:27-47

Tsou C-Y, Chigira M, Matsushi Y, Chen S-C (2015) Deep-seated gravitational deformation of mountain slopes caused by river incision in the Central Range, Taiwan: spatial distribution and geological characteristics. Eng Geol 196:126-138

Varnes DJ, Radbruch-Hall DH, Varnes KL, Smith WK, Savage WZ (1990) Measurement of ridge-spreading movements (Sackungen) at Bald Eagle Mountain, Lake County, Colorado, 1975-1989. Dept. of the Interior, US Geological Survey

Vernet J (1982) La phase d'édification post-miocène des alpes sur la transversale des Alpes-Maritimes. Bull Soc Hist Nat Toulouse 1:8

Zanchetta G, Regattieri E, Isola I, Drysdale RN, Bini M, Baneschi I, Hellstrom JC (2016) The so-called "4.2 event" in the central Mediterranean and its climatic teleconnections. Alpine Mediterr Quaternary 29:5-17

Zerathe S (2013) Origine et évolution des ruptures gravitaires de grande ampleur dans les chaînes subalpines méridionales à l'Holocène. Contraintes géomorphologiques, géochronologiques et géophysiques. Université Nice Sophia Antipolis

Zerathe S, Lebourg T (2012) Evolution stages of large deep-seated landslides at the front of a subalpine meridional chain (Maritime-Alps, France). Geomorphology 138:390-403

Zerathe S, Lebourg T, Braucher R, Bourlès D (2014) Mid-Holocene cluster of large-scale landslides revealed in the Southwestern Alps by $36 \mathrm{Cl}$ dating. Insight on an Alpinescale landslide activity. Quat Sci Rev 90:106-127. https://doi.org/10.1016/j.quascirev.2014.02.015 
Fig. 1: (a) Structural map of the Western South Alps (Sanchez 2010) and recent fault systems (in bold, proposed Holocene activity) (Sanchez et al. 2010). (b) Cross-section A-B: Simplified North-South section across the Western South Alps (Sanchez 2010), modified from Laurent (1998).

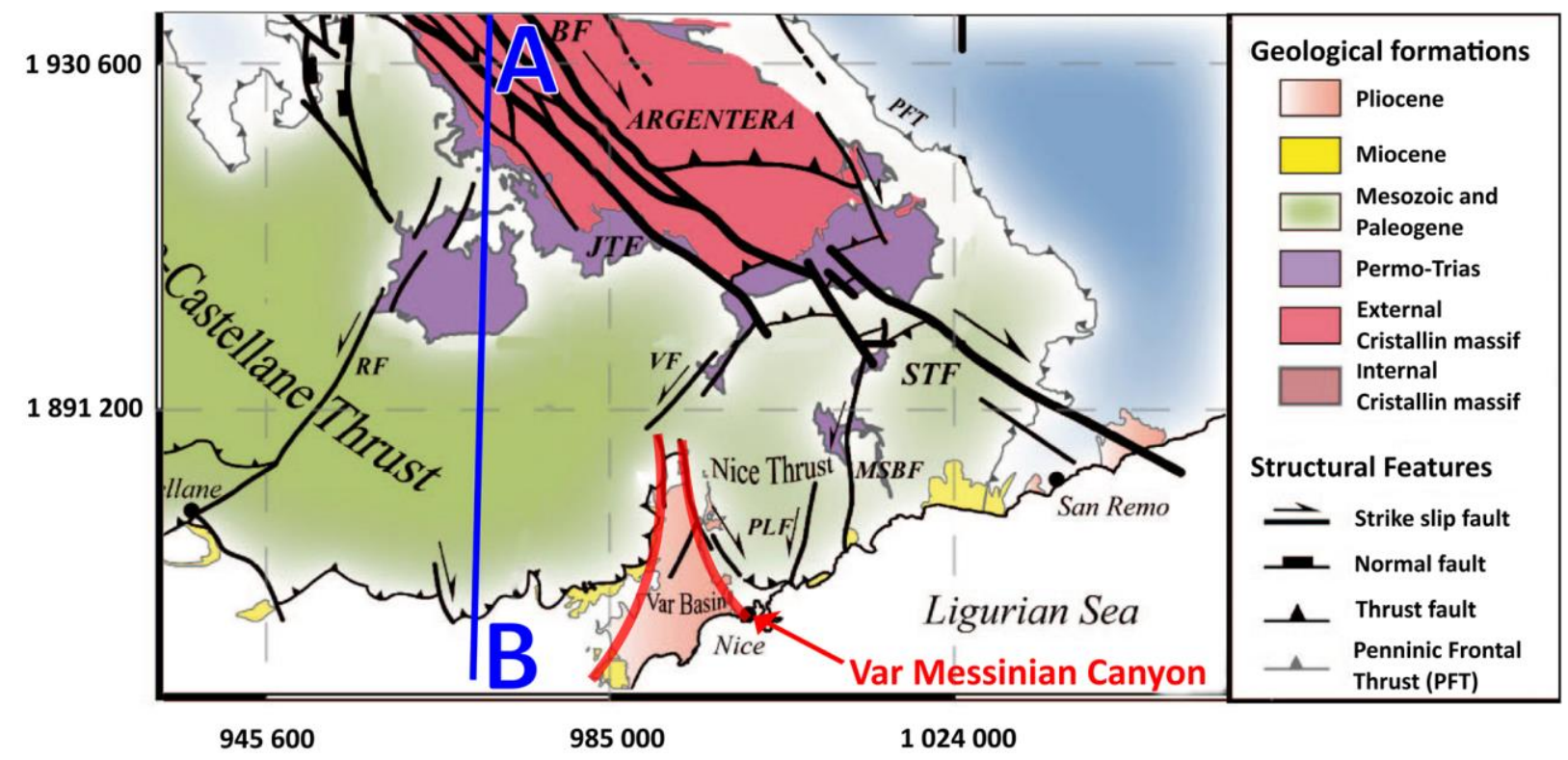

Description of Figure 1a BF: Bersézio fault; DCFT: Digne-Castellane Front Thrust; JTF: Jausier-Tinée fault; MSBF: Monaco-Sospel-Breil fault; NT: Nice Thrust; PFT: Peninic Frontal Thrust; PLF: Peile-Laghet fault; STF: Saorge-Taggia ault; VF: Vésubie fault. The blue line corresponds to the layout of the exposed section Figure $1 \mathrm{~b}$.

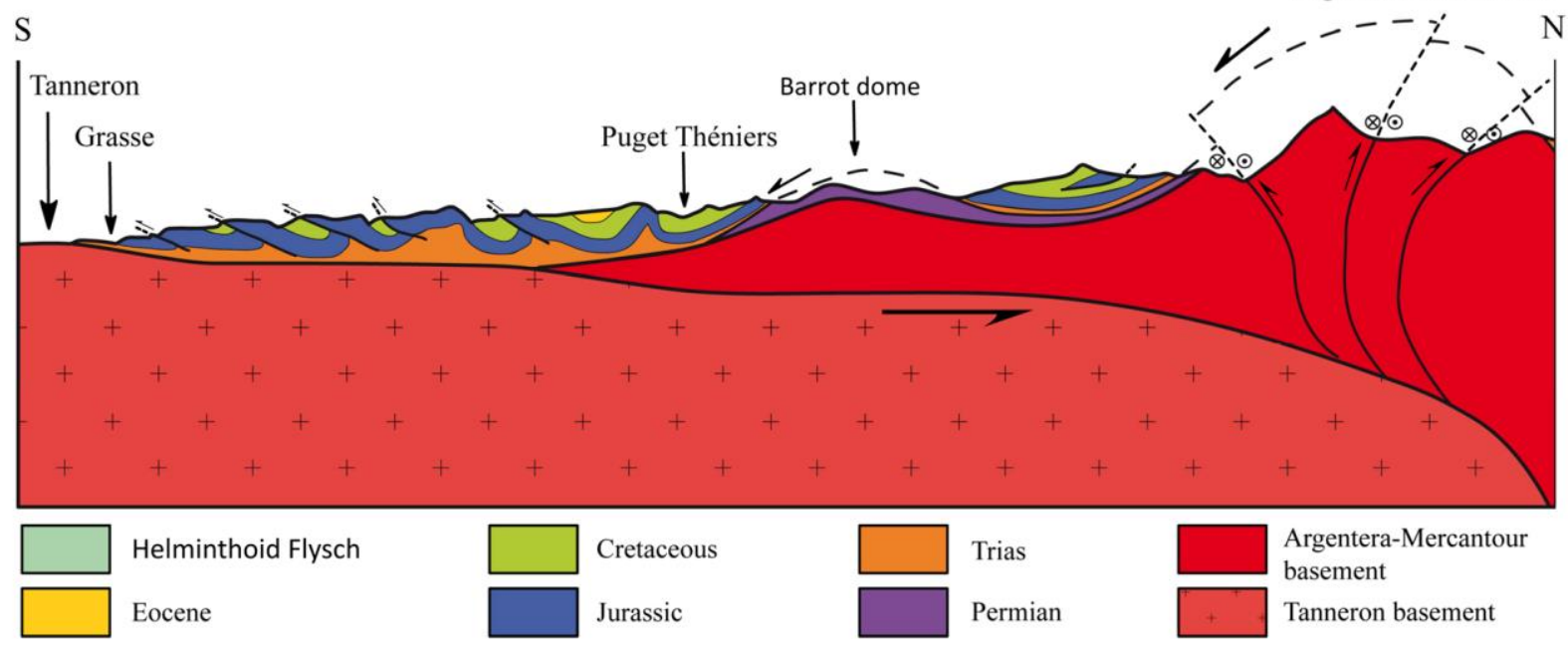


Fig. 2: (a) Geological map of the lower Var Valley at 1/5000000 (modified from Ginsburg et al. 1980). (b) Zoom on the Carros/Gattières area (1) Gattières DSL, (2) Ripert DSL, and (3) Carros DSL. (c) Geological section A-B Fig. $2 b$.

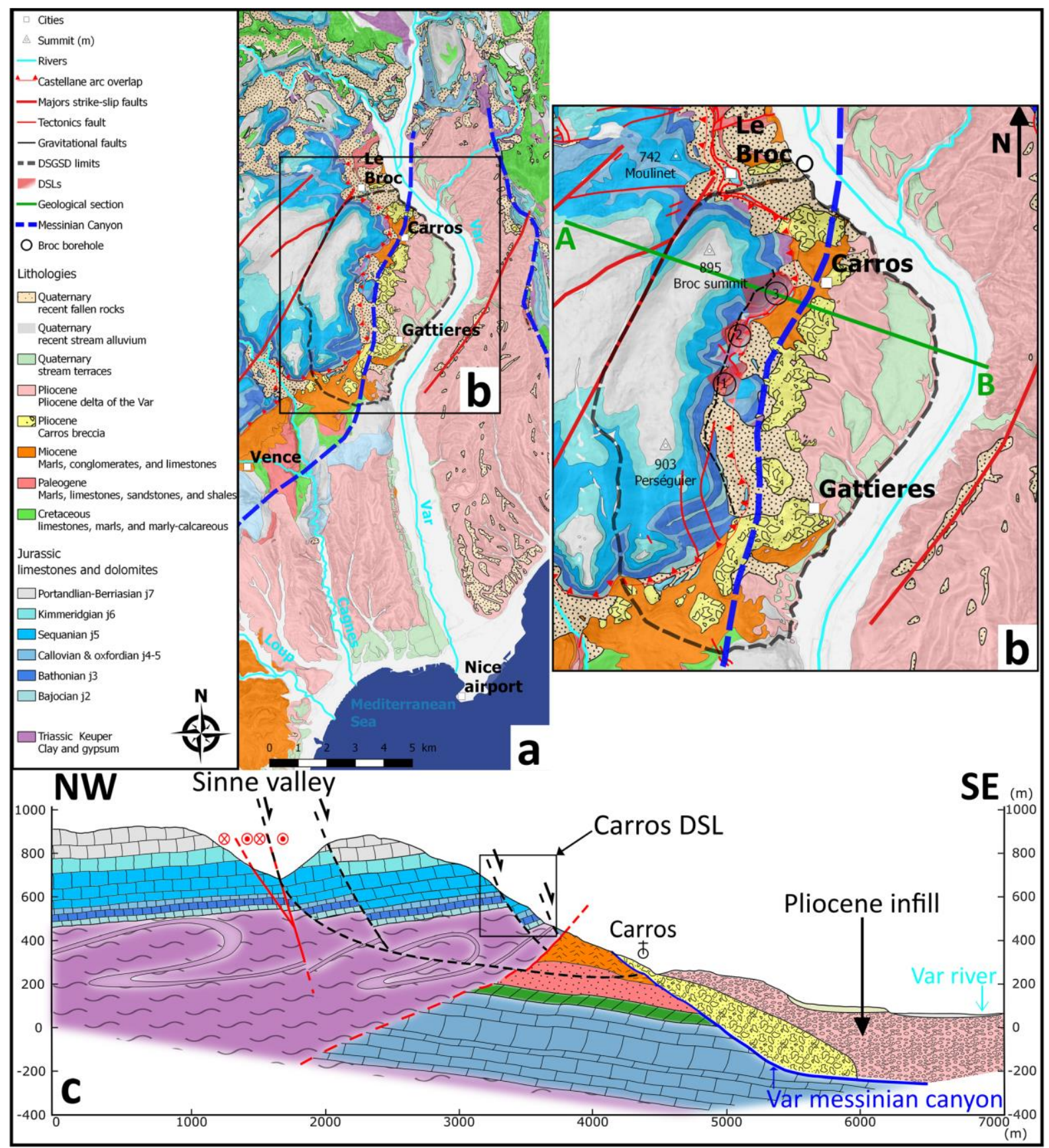


Fig. 3: 3D view of the area. (a) Cross-section M-N (Fig. 3e) Gattières DSL (modified from Zerathe (2013). (b) Average offset between the two plateaus and the Jurassic limestone formations between the two banks of the Sinne valley without formations dip (up) with formations dip (down). (c) Crevasse toward $\mathrm{N} 20-40^{\circ}$ in the limestone formations of the Sinne Valley (up to $2 \mathrm{~m}$ wide and $100 \mathrm{~m}$ long). (d) Gattières/Carros fault markers, crevasses in NW-SE extension. (e) 3D view of the Gattières/Carros side, geological map (up) roughness map (down)
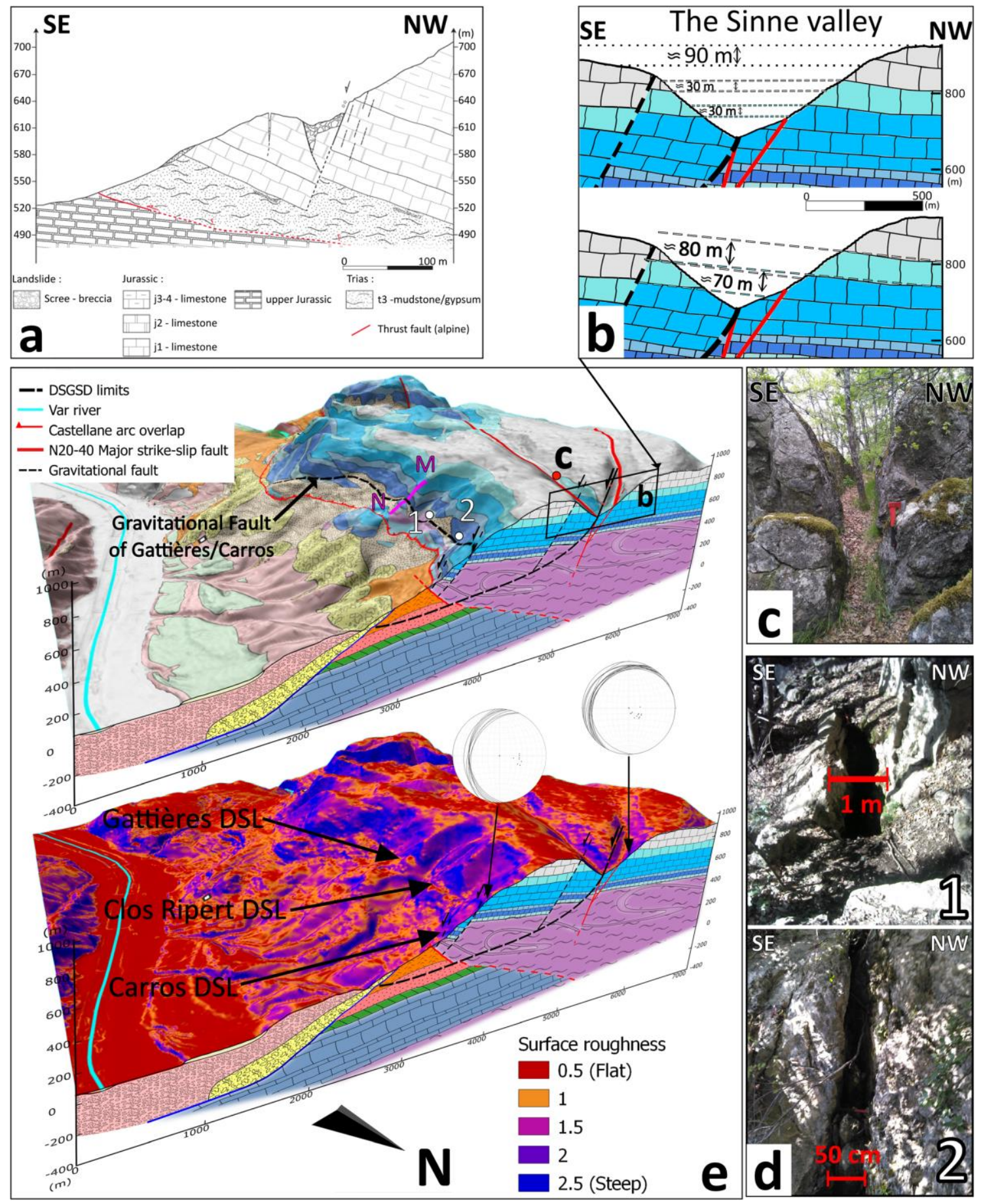
Fig. 4: (a) Foreset beds of Pliocene conglomerate at Le Broc (Carros breccia, Fig. 2). (b) Marine burrows on limestone blocks of the Carros breccia.
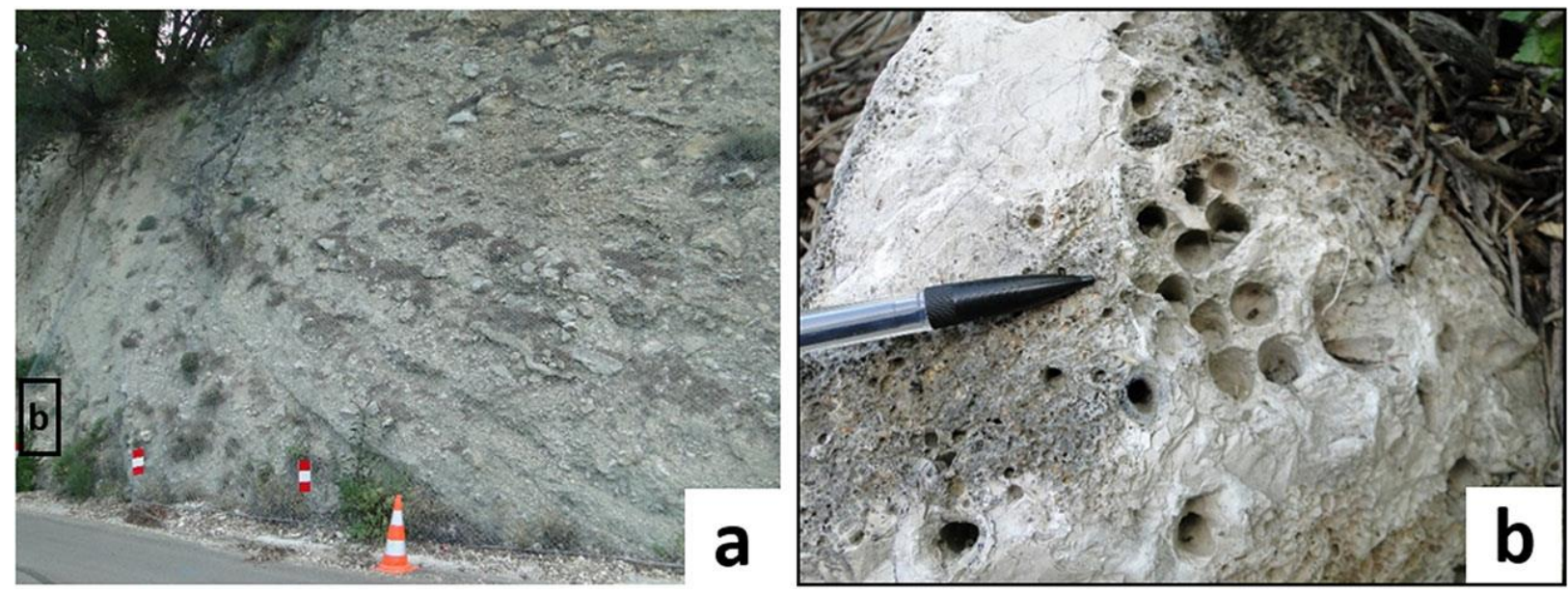

Fig. 6: Schematic interpretation of the processes that triggered the landslides in the case of the Gulf of Lion landslide $(A-C)(\sim 1.108 \mathrm{m3})$, the Nile valley landslide $(D-F)(\sim 2.108 \mathrm{m3})$, and the Alboran landslide $(G-I)$. The river erosion increased the slope gradient along the side slopes of valleys and the apparent relief $H$. The flooding of the Mediterranean Sea and incised valleys by seawater increased the pore pressure along the Messinian incised valleys (Gargani et al. 2014).

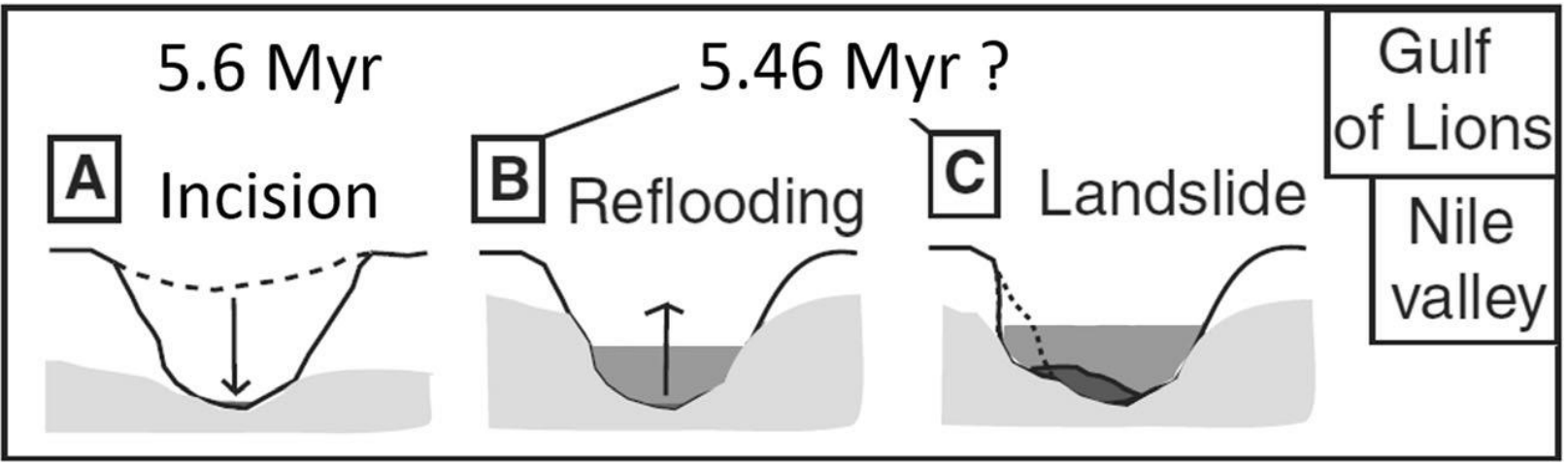


Fig. 5: Interpretations of geological events on the right bank of the Var at Carros from the Messinian (5.5 Ma). (A) Late Miocene. (B) Messinian crisis. (C) Pliocene. (D) Current. Geological layer and section position Fig. 2.

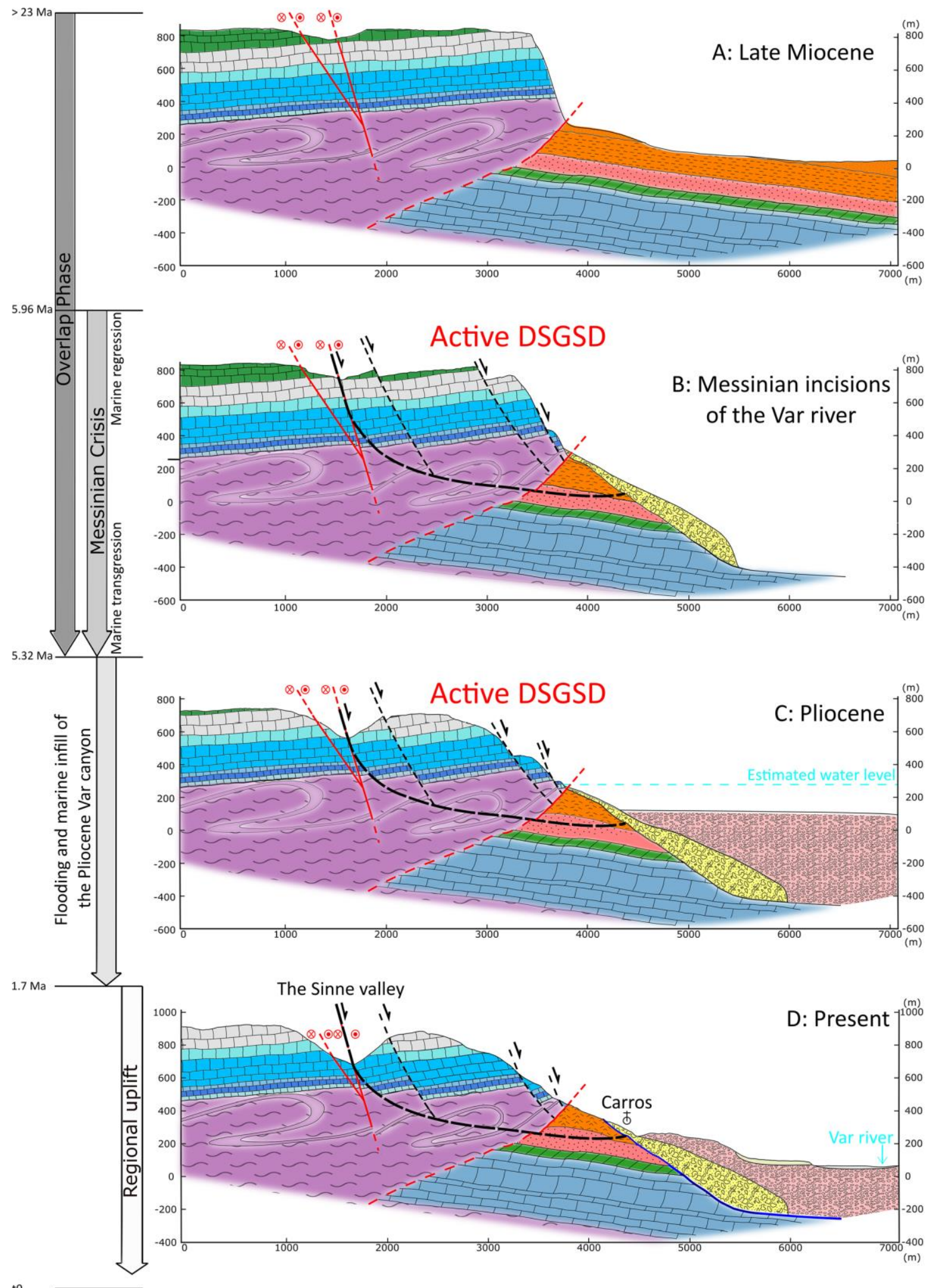

